\title{
Effect of calcium chloride on sodium alginate on the restructuring of fish products
}

\section{Radion Nykyforov ${ }^{1}$, Yurii Korenets ${ }^{1}$, Natalya Frolova ${ }^{2}$, Oleg Kuzmin ${ }^{2}$}

1 - Donetsk National University of Economics and Trade named after Mykhailo TuganBaranovsky, Kryvyi Rih, Ukraine

2- National University of Food Technologies, Kyiv, Ukraine

Keywords:

Fish

Carp

Restructured

Sodium alginate

Fillets

\section{Article history: \\ Received 16.11.2018 \\ Received in revised \\ form 28.03.2019 \\ Accepted 30.09.2019}

\section{Corresponding author:}

Radion Nykyforov

E-mail:

nykyforov@

donnuet.edu.ua

DOI: $10.24263 / 2304-$

974X-2019-8-3-14

\section{Abstract}

Introduction. The purpose of this publication is to investigate the mechanism of the restructuring of fishery products using calcium chloride and sodium alginate.

Materials and methods. Minced fish fillet of carp (protein $16.5 \pm 0.2 \%$; fats $-1.2 \pm 0.03 \%$, minerals $-1.3 \pm 0.03 \%$ ); structure-forming agents are sodium alginate, calcium chloride $\left(\mathrm{CaCl}_{2}\right)$. The method of rotational viscometry - rheological characteristics; the method of energy absorption in the mid-wavelength range of the infrared spectrum - energy substances; spectrophotometry method and X-ray fluorescence method mineral composition; descriptive and profile method - organoleptic indicators.

Results and discussion. Adding to the minced meat to $1.0 \%$ of sodium alginate leads to an increase in the effective viscosity of the system to $3.6 \cdot 10^{-3}$ $\mathrm{Pa} \cdot \mathrm{s}$ (shear rate $\varepsilon=1.8 \mathrm{~s}^{-1}$ ). Increasing the concentration of sodium alginate from 2 to $3 \%$ leads to a similar increase in the effective viscosity from 6.9.10 ${ }^{3}$ to $12.6 \cdot 10^{-3} \mathrm{~Pa} \cdot \mathrm{s}$. At the same time, it was proved that the addition of sodium alginate with a concentration of $2.0 \%$ ensures the complete formation of the structure of fishery products in the process of its formation.

It has been established that the process of structuring fishery products is intensified due to the duration of holding the fish mince/alginate system in a 5 $\%$ solution of $\mathrm{CaCl}_{2}$ for (6-7). $60 \mathrm{~s}$ at the required level of effective viscosity. Increased structuring time (>7.60 s) and subsequent formation lead to a further deterioration of organoleptic characteristics - the appearance of bitter taste, in the presence of free calcium ions.

On the basis of the study it is proved that in the concentration range of sodium alginate 1-3\% there is an increase of water-holding capacity of fish products by $1.27-1.45$ times. The maximum value of organoleptic indicators -5 points received fish products with a concentration of sodium alginate 2.0 $2.5 \%$. Further increase in the concentration of sodium alginate from 2.5 to $3.0 \%$ leads to an increase in the effective viscosity and gel-forming ability of the system and characterizes the samples with reduced organoleptic characteristics, which are characterized by the rigidity of the structure.

Conclusions. The obtained experimental data prove the influence of technological parameters and their rational values: the concentration of sodium alginate in the prescription mixture $-2.0-2.5 \%$; concentration of calcium chloride in solution $-5.0 \%$; the processing time of the formed samples in solutions of calcium chloride - (6-7).60 s on the mechanism of restructuring of fishery products. 


\section{- Food Technology -}

\section{Introduction}

The above study relates to the food (Kuzmin et al, 2017) [1] and restaurant industry (Kuzmin et al, 2017) [2], namely, to the fish processing industry (Santeramo et al, 2018; Augustin et al, 2016; Pihlajamäki et al, 2018) [3-5]. An important place in human nutrition is taken by the consumption of fish (Anderson et al, 2018; Clark et al, 2018; Fabinyi et al, 2018; Skopenko, Tikhonova, 2013; Raišienė, Morkūnas, 2018; Solomianiuk et al, 2019) [6-11] and non-fish seafood (Anderson et al, 2018; Clark et al, 2018; Fabinyi et al, 2018) [6-8]. This is primarily due to the high nutritional and biological value of this product group and its high consumer properties (Popa et al, 2019; Ariño et al, 2013; Leonardo et al, 2016; Aberoumand, Ziaei-Nejad, 2015; Krumhout, de Goede, 2014; Raji et al, 2014; Butler et al, 2017; Keskin et al, 2019) [12-19].

Nowadays, the quality and assortment of fish products consumed in depends on the global market trends, most of which are increase prices for traditional fish raw materials (Biloukha, Utermohlen, 2000) [20], decrease in the volume of its catch (Martins et al, 2018) [21], impossibility of importing new types of fish, which is limited by law.

Most of the fish species studied are safe to be consumed. Therefore, this study is proposed to draw the attention of health and environmental authorities in need for appropriate regulatory framework (Jothi et al, 2018) [22].

In consequence of the technology of complex processing of raw fish materials (Samsonov et al, 2013; Huang et al, 2019; Tolosa et al, 2017; Han et al, 2017; Grassi et al, 2018) [2327] from the country's inland water bodies (carps, silver carps, etc.) becomes important, whereby there is a reduction of depending on the external market, more rational use of the edible part of fish is provided, the range of fish products is expanded, and fuller use of raw materials for food purposes is provided.

Previous works reported the effect of processing methods on different fish types for determination of them nutritive values (Aberoumand, Ziaei-Nejad, 2015) [15].

In recent years, the processing of fish raw materials for mince and protein preparations has become widespread, followed by the formation of structured products based on them, including various analogues with a given composition and organoleptic properties, such as crab sticks (Otero et al, 2017; Campo-Deaño, Tovar, 2009; Hur et al, 2011) [28-30], crustacean meat analogues, and caviar of valuable fish species, etc. However, systematic studies aimed at obtaining a restructured fish product from fish in the country's inland waters have not found in the literature.

So, for today, the processing of carp fish species (Liu et al, 2016; Gao et al, 2019; Xu et al, 2010; An et al, 2018; Zhang et al, 2018; Abdollahi et al, 2017; Liu et al, 2014) [31-37] into structured analogues is hampered by an insufficient level of scientific researches, the lack of scientific bases for processing specific types of raw materials. Considering this, the development of a scientifically-based competitive technology of structured analogs of carp fillets for cooking is extremely important.

The aim of the publication is to develop a method of minced carp producing and determination of the effect of calcium chloride on sodium alginate on the restructuring of fish products. 


\section{- Food Technology}

\section{Materials and methods}

\section{Materials}

The subject of the study was selected mince, which was prepared from carp fillets (Grassi et al, 2018) [27]. At the first stage of research, the modes of mechanical processing of fish carcasses were justified (Liu, 2016) [31].

During the research, gutted frozen carp carcasses with a weight up to $300 \mathrm{~g}$ were used.

Defrosting was carried out in air (Xu et al, 2010) [33]. Fish was washed in running water (An et al, 2018) [34]. Flake removal was not performed. The blood kidney located under the vertebral bone was removed (Zhang et al, 2018) [35]. Cut off the head, cut carcasses and separated the fillets without skin and bones. Received food waste was directed to the production of feed products, it is known (Xu et al, 2010; An et al, 2018; Zhang et al, 2018) [33-35] that the cost of processing them for food purposes exceeds the profit obtained from the increase in production.

\section{Description of methods}

Sampling, leaching of mass of dry solids, ash and carried out by conventional methods (Horalchuk et al, 2006) [38].

The rheological parameter investigated is accessible by the method (Horalchuk et al, 2006) [38]. With early use of the cylinder system $S 2$ with a joyful clearance of $1.13 \cdot 10^{-3} \mathrm{~m}$ and a radius ratio of 1.06 . A sample volume $(30 \pm 1.5) \cdot 10^{-3} \mathrm{dm}^{3}$ was placed into the outer steel cylinder, which is a measuring capacity of radius $r$. An inner cylinder of radius $r_{\mathrm{b}}$ and height $l$ rotating at a constant velocity $\omega$ is connected through a measuring shaft to a cylindrical spring, the deviation of which is a measure of the torque $M$. The measurement system with zoom once is thermostatically controlled for $30 \mathrm{~min}$. with the moment of torque activation. Measurement results were processed by the method (Horalchuk et al, 2006) [38].

Determination in macro and microelements allows us to estimate the $X$-ray fluorescence method on a spectrometer Spectroscan. Protein, fat, ash, and solids content were measured on a Bentley-150 device (Moore et al, 2009) [39].

The minimum composition was determined by the method of spectrophotometry on the atomic absorption spectrophotometer $A A S$-30 (Almeida, 2016) [40].

Sensory analysis of the samples was performed using descriptive and profile methods using a five-point scale (Kuzmin et al, 2018) [41].

\section{Description of research procedure}

As a result of the research, data were obtained on the yield of individual anatomical parts, are shown in Table 1.

Output of the anatomical parts of the carp

Table 1

\begin{tabular}{|c|c|}
\hline Title & Carp with a weight up to 300 g \\
\hline Meat & $49.0 \%$ \\
\hline Food waste & $47.1 \%$ \\
\hline Losses & $3.9 \%$ \\
\hline
\end{tabular}


Studies of the literature (Liu et al, 2016; Gao et al, 2019; Xu et al, 2010; An et al, 2018) [31-34] have shown that carp is characterized by a specific "silty" smell, which can be removed by flavoring.

An aromatization mixture was developed, by tasting workings, including mustard (1.2\%), garlic $(0.65 \%)$, vinegar $(3,0 \%)$.

To substantiate the aromatization regime, the fish fillet was kept in the aromatization mixture for $40.60 \mathrm{~s}$ at a temperature not higher than $18^{\circ} \mathrm{C}$. At the same time, the organoleptic properties of the fish were controlled, pre exposing its poaching. The results of the research are given in Table 2 .

Table 2

\section{Dependence of the organoleptic properties of fillets on the duration of aromatization}

\begin{tabular}{|c|c|}
\hline Aromatization time, $\mathbf{s}$ & The presence of "silty" smell \\
\hline $10 \cdot 60$ & Expressed \\
\hline $20 \cdot 60$ & Mild \\
\hline $30 \cdot 60$ & Absent \\
\hline $40 \cdot 60$ & Absent \\
\hline
\end{tabular}

It is established that the exposure of carp fillet in the aroma mixture for $30.60 \mathrm{~s}$ allows to completely eliminate the "silty" smell. Thus, finished products palatability increased.

Milling of fish mass was carried out in two stages. First, the mass was passed through a meat grinder with a hole diameter of $3 \mathrm{~mm}$. It was established that the intermuscular bone tissue of carp has a small strength and freely crushed to the specified sizes. Re-grinding was carried out on the cutter.

Processing of carp by this technology allows increasing the biological value of finished culinary products due to the elements of the chemical composition of bone tissue.

At the next stage, the chemical composition of the minced meat was investigated. The results of the study are given in Table 3 .

Chemical composition of minced meat

Table 3

\begin{tabular}{|c|c|}
\hline Indicator & Mass fraction to raw weight, \% \\
\hline Solids, including: & $19.0 \pm 0,2$ \\
\hline Proteins & $16.5 \pm 0,2$ \\
\hline Fats & $1.2 \pm 0,03$ \\
\hline Minerals & $1.3 \pm 0,03$ \\
\hline
\end{tabular}

It is known (Kuzmin et al, 2017) [42] that during the storage of minced meat its structural and mechanical properties change significantly, accompanied by compaction of the structure due to the appearance of chemical bonds between proteins. At the same time minced meat presses moisture (Kuzmin et al, 2017) [42]. Reducing of meat stuffing and moisture loss is possible by reducing the concentration of solids (Kuzmin et al, 2017) [42]. 


\section{Results and discussions}

To study the effect of the solids content on the structural and mechanical properties of minced meat, drinking water was added to it to a solids content of $9.0 \%$. The results of the study are shown on Figure 1.

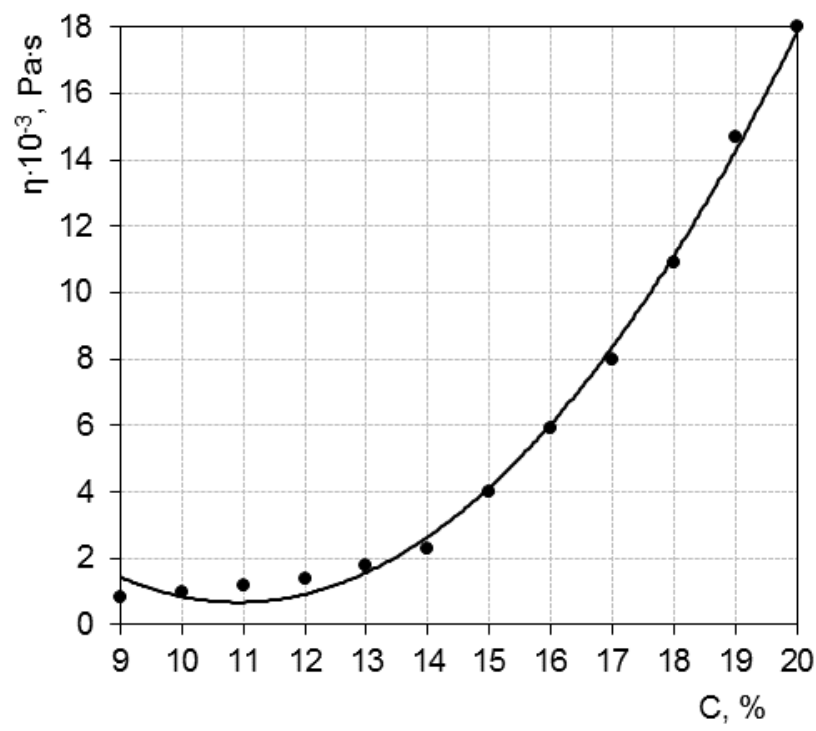

Figure 1. Dependence of the effective viscosity of minced carp $(\eta)$ from the concentration of dry substances (C)

It has been established that a decrease of solids concentration and a protein component in particular, leads to viscosity of minced meat decrease. So, decrease of dry substances concentration from 19.0 to $9.0 \%$ for minced carp, the viscosity decreases by 29.2 times.

It was found that during storage, pressing of moisture is not observed in minced carp at a humidity of $11.0 \%$. Therefore, these concentrations of dry substances are rational for restructured minced meat, which will ensure the fluidity of minced meat during formation.

At the same time, due to the protein interaction, the minced meat obtained during cooling and heating is not capable of forming homogeneous stable gels that imitating fish meat (Xu et al, 2010; An et al, 2018; Zhang et al, 2018) [33-35]. Therefore, it is necessary to attract additional gelation factors.

Regulation of the functional and technological properties of minced meat can be achieved by intake into its composition food ingredients that can simultaneously change the structural and mechanical parameters and increase the structuring ability (Xu et al, 2010) [33]. Sodium alginate meets these requirements, which, at certain concentrations, can increase the viscosity and the formative capacity of the prescription mixture, and allows ionotropic gelation to be used along with thermotropic ones (Khairou et al, 2002) [43]. At the same time, this makes it possible to avoid certain restrictions of prescription mixture of the formulation, in particular, the formation of a gel when the concentration of gel-forming protein compounds is lower than the critical one (Pérez-Mateos et al, 2002) [44].

The choice of sodium alginate as a gelling agent simultaneously takes into account the following requirements (Moreno et al, 2010) [45]: 
- sodium alginate is compatible with the components of meat and can form gels in the presence of various nutrients, particular, proteins;

- it is able to form gels with a complex of physico-chemical parameters that will provide the necessary texture of the product, suitability for long-term storage;

- its using makes it possible to regulate the speed of the gelation process, particular, the course of the liquid system in a gel-like state;

- the absence of toxic and allergic effects, it is has simultaneously low cost.

It is known (Montero, Pérez-Mateos, 2002) [46] that a sufficient height of gelation of minced masses can be achieved with sodium alginate content up to $3 \%$.

At the next stage, the dependence of the viscosity of minced fish on the content of sodium alginate was investigated at a shear rate $\varepsilon=1,8 \mathrm{~s}^{-1}$ (Figure 2).

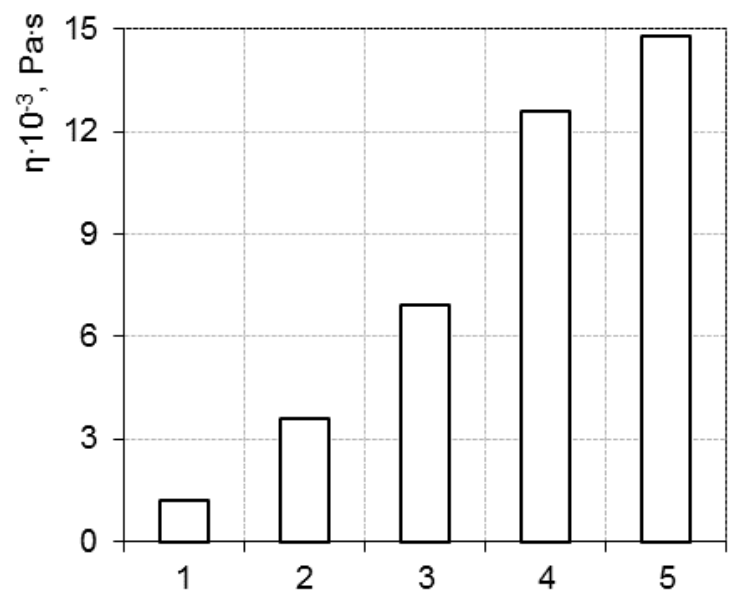

Figure 2. Dependence of the effective viscosity of the samples on the content of sodium alginate: 1 - minced carp with a moisture content of $11.0 \%$ (control); $2,3,4$ - minced carp with a moisture content of $11.0 \%$ with the addition of $1.0 \%, 2.0 \%, 3.0 \%$ sodium alginate, respectively; 5 - minced carp with a moisture content of $19.0 \%$

From the data shown on Figure 2, it is seen that the addition of sodium alginate leads to an increase in the viscosity of the systems. So, at a sodium alginate concentration of $1.0 \%$, the viscosity of the systems is $3.60 \cdot 10^{-3} \mathrm{~Pa} \cdot \mathrm{s}$. The introduction of sodium alginate in concentrations of $2.0-3.0 \%$ increases the viscosity to $(6.9-12.6) \cdot 10^{-3} \mathrm{~Pa} \cdot \mathrm{s}$ and provides a continuous structure of prescription mixture. The best structure is observed when the alginate content is $2 \%$, and the moisture does not precipitate.

Such minced systems are guaranteed ensure, within a certain time, the retention of a given shape when an extruded mass enters the liquid process medium, where the structure is consolidated (gelation) (Moreno et al, 2010) [45].

The obtained minced systems were subjected to heat treatment, which showed that for all the studied concentrations of sodium alginate, minced systems with a solids content of 11.0 $\%$ are not capable of forming thermotropic gels. Therefore, to obtain elastic gels, it is necessary to realize the ability of sodium alginate in ionotropic gelation (Khairou et al, 2002) [43]. 
Ionotropic gelation is a purely chemical process (Khairou et al, 2002) [43], so it is important to determine the parameters that ensure the progress of this reaction, the dynamics and the completeness of its completion. Whereas ionotropic gelation is associated with mass transfer of interacting components, it is necessary to determine rational concentrations that provide, on the one hand, ion-ion interaction, and on the other, the necessary structure indicators in accordance with the requirements of organoleptic indicators.

Extrusion molding a prescription mixture with sodium alginate content up to $3.0 \%$ followed by processing samples in calcium chloride solutions always leaves the conditions of a more significant concentration excess of $\mathrm{Ca}^{2+}$ ions over $\mathrm{AlgCOO}^{-}$ions, which is guaranteed to ensure gelation. In the case of high concentrations of $\mathrm{Ca}^{2+}$ ions in solutions, short exposure to the solution is used; at low concentrations of $\mathrm{Ca}^{2+}$ ions in solutions, the processing time is increased. As a source of calcium ions, a solution of calcium chloride was chosen, the concentration of which was $5.0 \%$.

From the point of view of the implementation of technology restructured products is important to ensure the necessary organoleptic characteristics of the final products, therefore indicators such as the concentration of sodium alginate, calcium chloride and sample processing time in solutions of calcium chloride are key parameters of the process. The principle fact is in addition to the reaction, it is necessary to ensure the organoleptic characteristics of the product.

The effect of the duration of exposure of meat in a solution of calcium chloride and the concentration of sodium alginate on the structural and mechanical properties of meat were investigated (Figure 3).

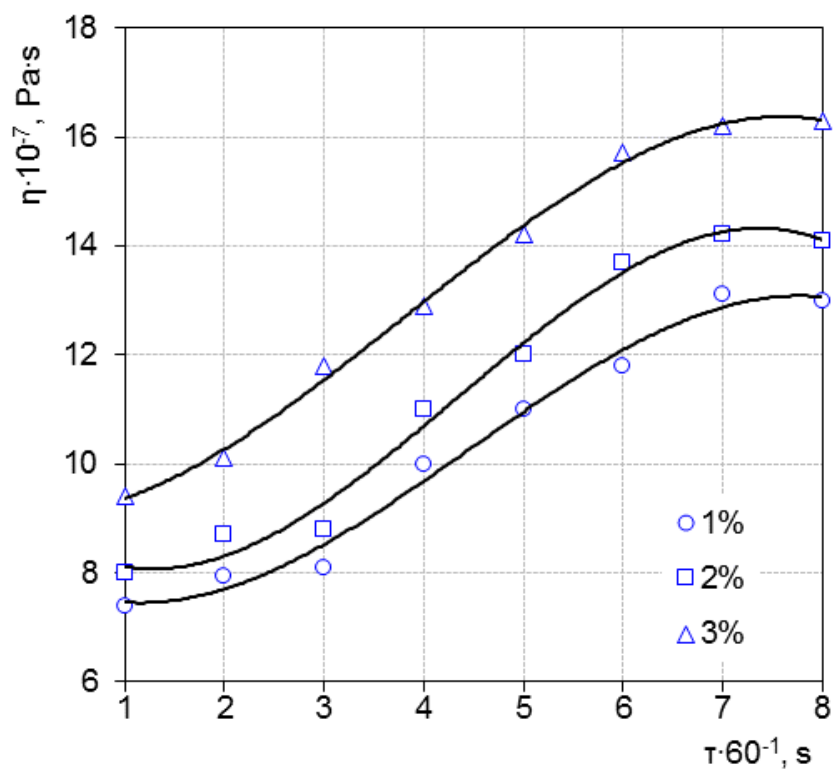

Figure 3. The dependence of the effective viscosity on the duration of structuring: minced meat with the addition of $1,2,3 \%$ sodium alginate, respectively 
It was established that under all treatment conditions in $\mathrm{CaCl}_{2}$ solutions with an increase the concentration of sodium alginate in the prescription mixture in the range of 1-3\%, increase the viscosity of the samples occurs. Increasing the processing time of samples in a solution of calcium chloride also contributes to viscosity increase. When the concentration of sodium alginate in the systems is $2 \%$ and $3 \%$, the viscosity increases respectively 1.08 and 1.3 times. With an increase of processing time from $1.60 \mathrm{~s}$ to $7.60 \mathrm{~s}$, the viscosity increases, respectively, 1.78 and 1.83 and 1.77 times for systems with sodium alginate contents of $1,2,3 \%$ respectively. With further aging, viscosity growth almost does not occur.

The described patterns can be explained by the fact that over time the number of calcium bridges between the individual chains of sodium alginate molecules increases, which leads to their crosslinking and the formation of the spatial structure of the gel; with a low content of the amendment in the system, the distance between the macromolecules of sodium alginate is significant, so the formation of a solid gel network does not occur (Yong, Mooney, 2012) [47].

Thus, the most rational concentrations of sodium alginate, the required viscosity level of the structured systems is provided, lies in the range of $2.0-3.0 \%$ with a duration of formation (6-7).60 s.

The increase of structuring time causes the appearance of a bitter taste due to the presence of free calcium ions, which did not react with sodium alginate (Senturk Parreidt et al, 2018) [48].

Along the study of the structural and mechanical characteristics changes, some of its functional and technological properties, particular, its water-retaining capacity, was determined (Figure 4).

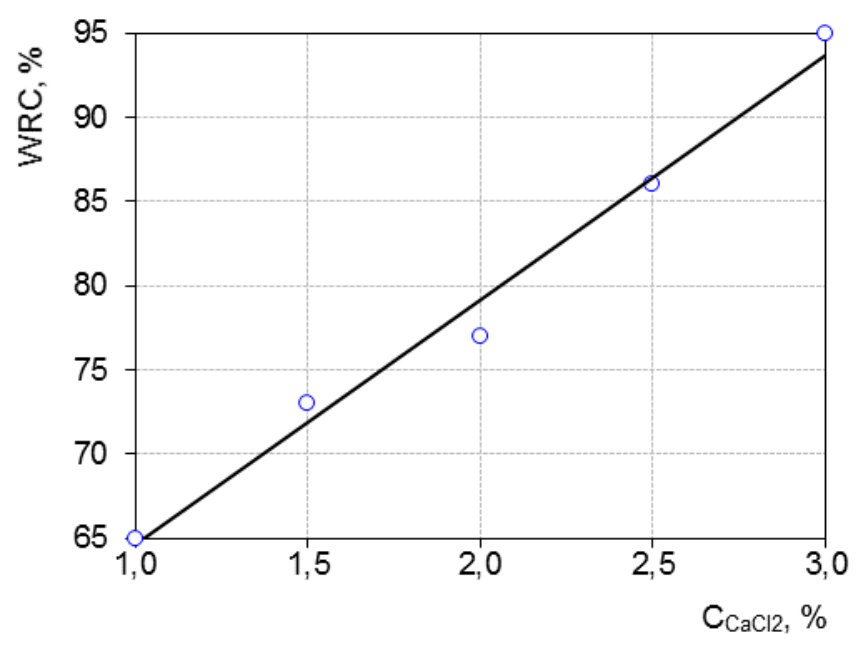

Figure 4. Dependence of the water-retaining capacity (WRC) of gels from the concentration of sodium alginate: $\left(C_{C a C I}=5 \%, \tau=7 \cdot 60 \mathrm{~s}\right)$

It has been established that sodium alginate in the concentration range of 1.0-3.0\% contributes to increase in the water-retaining capacity of samples by 1.45 times - from $64 \%$ to $93 \%$. At a concentration of sodium alginate of $2.0 \%$ (compared to $1.0 \%$ ), the waterretaining capacity of the systems increases by 1.27 times - from $64 \%$ to $81 \%$. A further increase the concentration of sodium alginate also leads to water-retaining capacity increase, 
the value of which increases 1.15 times. This can be explained by the fact that, all other things being equal, with an increase the concentration of the gelling agent, the residual amount of sodium alginate, that did not take part in the ion exchange reaction, increases, that causes an increase of water-retaining capacity (Tønnesen, Karlsen, 2002) [49].

In parallel with the determination of the water-retaining capacity, an organoleptic assessment of ionotropic gels was carried out. It was established that the maximum number of points (5) correspond to samples with the concentration of sodium alginate $2.0-2.5 \%$. An increase the concentration of the gelling agent to $3.0 \%$ (with a simultaneous increase of the water-retaining capacity), the samples are characterized as too rigid. That is, exceeding the concentration of sodium alginate with $2.5 \%$ leads to the fact that ionotropic gels become uncharacteristic for fish meat that causes a decrease of organoleptic characteristics.

Thus, the conducted studies and results of organoleptic assessment allowed determining the rational values of the technological parameters of the formation of restructured systems based on minced fish that are listed in Table 4.

Table 4

\section{Rational parameters for producing a restructured semi-finished product}

\begin{tabular}{|l|c|c|}
\hline \multicolumn{1}{|c|}{ Parameters' title } & Units of measurement & Limiting values \\
\hline $\begin{array}{l}\text { The concentration of } \\
\text { sodium alginate in the } \\
\text { prescription mixture }\end{array}$ & $\%$ & $2.0 \ldots 2.5$ \\
\hline $\begin{array}{l}\text { The concentration of } \\
\text { calcium chloride in the } \\
\text { solution }\end{array}$ & $\%$ & 5.0 \\
\hline $\begin{array}{l}\text { The processing time of the } \\
\text { formed samples in } \\
\text { solutions of calcium } \\
\text { chloride }\end{array}$ & $60, \mathrm{~s}$ & $6-7$ \\
\hline
\end{tabular}

Conducted researches allowed determining the rational content of the main prescription components and developing a technological scheme for the production of semi-finished products. The technological process is carried out in the following sequence:

- minced fish, solutions of sodium alginate, salt, sugar, egg powder, starch, sunflower oil combine and mix thoroughly, until the components are evenly distributed in the recipe mix;

- prescription mixture formation carrying out by using a pressure press, for which the mass is spread on the forms and press the press to seal the structure;

- formed prescription mixture is fed to the reception bath with a calcium chloride solution of $5.0 \%$ concentration and kept at a temperature $8-20{ }^{\circ} \mathrm{C}$ for $(6-7) \cdot 60 \mathrm{~s}$ for structuring;

- structured semi-finished products, that are located in perforated containers, are treated in $0.15 \%$ sodium alginate solution at a temperature $18-20{ }^{\circ} \mathrm{C}$ in order to remove excess free $\mathrm{Ca}^{2+}$ ions;

- semi-finished products processed in sodium alginate solutions are sent to a cooled chamber at a temperature $2-6{ }^{\circ} \mathrm{C}$ for $(0.5-1.0) \cdot 60^{2} \mathrm{~s}$ for fixing a structure. 


\section{- Food Technology -}

\section{Conclusions}

Fish product from carp, obtained according to that technological scheme, is a semifinished product of high degree of readiness, which by its organoleptic properties imitates fish meat. This product is new in the existing assortment of restructured fish products; therefore it is advisable to investigate its main indicators of quality in the future.

Conducted researches allowed us to develop recommendations on the use of fish product from carp in the composition of culinary products and determine the effect of calcium chloride on sodium alginate on the restructuring of fish products. It has been established that fish product from carp can be used in the production of cold dishes and snacks, hot snacks, soups, fish dishes, etc.

Summing up the results of research, it should be noted that the use of fish product from carp in the composition of culinary products allows to expand its range, offer products with new consumer properties, improve the efficiency of the enterprises of restaurant business through the use of products in the form of semi-finished products.

\section{References}

1. Kuzmin O., Suikov S., Koretska I., Matiyashchuk O., Poliovyk V. (2017), Identification of equilibrium state of hydroxyl protons in vodkas by ${ }^{1} \mathrm{H}$ NMR spectroscopy, Ukrainian Food Journal, 6 (2), pp. 314-336.

2. Kuzmin O., Zubkova V., Shendrik T., Korenets Y., Kuzmin A., Bilenkyi P. (2018), Internal mechanisms for establishment of the equilibrium state of water-alcohol mixtures in vodka technology, Ukrainian Food Journal, 7 (4), pp. 655-670.

3. Santeramo F.G., Carlucci D., de Devitiis B., Seccia B., Nardone G. (2018), Emerging trends in European food, diets and food industry, Food Research International, 104, pp. 39-47.

4. Mary Ann Augustin, Malcolm Riley, Regine Stockmann, Louise Bennett, Lynne Cobiac (2016), Role of food processing in food and nutrition security, Trends in Food Science \& Technology, 56, pp. 115-125.

5. Mia Pihlajamäki, Simo Sarkki, Päivi Haapasaari (2018), Food security and safety in fisheries governance - A case study on Baltic herring, Marine Policy, 97, pp. 211-219.

6. James L. Anderson, Frank Asche, Taryn Garlock (2018), Globalization and commoditization: The transformation of the seafood market, Journal of Commodity Markets, 12, pp. 2-8.

7. Timothy P. Clark, Stefano B. Longo, Brett Clark, Andrew K. Jorgenson (2018), Sociostructural drivers, fisheries footprints, and seafood consumption: A comparative international study, 1961-2012, Journal of Rural Studies, 57, pp. 140-146.

8. Michael Fabinyi, Wolfram H. Dressler, Michael D. Pido (2018), Moving beyond financial value in seafood commodity chains, Marine Policy, 94, pp. 89-92.

9. Skopenko N., Tikhonova A. (2013), Rational assortment portfolio in accordance to the food security, Ukrainian Food Journal, 2(4), pp. 612-617.

10. Agota Giedrè Raišienè, Mangirdas Morkūnas (2018), Towards Healthier Life: Changes in growing of healthfriendly food crops and products in Lithuania before accession to EU and after, Ukrainian Food Journal, 7(2), pp. 337-351.

11. Solomianiuk N., Fedulova I., Dragan O. (2019), Relation of qualitative and quantitive levels of availability and adequacy of food in determing the level of food safety, Ukrainian Food Journal, 8(2), pp. 386-399. 
12. Mona Elena Popa, Amalia Carmen Mitelut, Elisabeta Elena Popa, Andreea Stan, Vlad Ioan Popa (2019), Organic foods contribution to nutritional quality and value, Trends in Food Science \& Technology, 84, pp. 15-18.

13. A. Ariño, J.A. Beltrán, A. Herrera, P. Roncalés (2013), Fish and seafood: Nutritional Value, Encyclopedia of Human Nutrition (Third Edition), pp. 254-261.

14. Raphael Leonardo, Raquel Soares Casaes Nunes, Maria Lúcia G. Monteiro, Carlos Adam Conte-Junior, Vânia M. F. Paschoalin (2016), Molecular testing on sardines and rulings on the authenticity and nutritional value of marketed fishes: An experience report in the state of Rio de Janeiro, Brazil, Food Control, 60, pp. 394-400.

15. Ali Aberoumand, Saeed Ziaei-Nejad (2015), Effects of processing on the proximate composition and energetic values in two fish species from Iran southern waters, Ukrainian Food Journal, 4(2), pp. 281-287.

16. Krumhout D., de Goede J. (2014), Update on cardiometabolic health effects of $\omega-3$ fatty acids, Current Opinion in Lipidology, 25(1), pp. 85-90.

17. Raji C.A., Erickson K.I., Lopez O.L., Kuller L.H., Gach H.M., Thompson P.M., Riverol M., Becker J.T. (2014), Regular Fish Consumption and Age-Related Brain Gray Matter Loss, American Journal of Preventive Medicine, 47(4), pp. 444-451.

18. Butler L.J., Janulewicz P.A., Carwile J.L., White R. F., Winter M.R., Aschengrau A. (2017), Childhood and adolescent fish consumption and adult neuropsychological performance: An analysis from the Cape Cod Health Study, Neurotoxicology and Teratology, 61, pp. 47-57.

19. İrfan Keskin, Bayram Köstekli, Asiye Eyuboğlu, Yalçın Kaya (2019), Determination of the shelf life of smoked sea bass (Dicentrarchus labrax linaeus, 1758) marinade stored under refrigerated conditions $\left(4^{\circ} \mathrm{C}\right)$, Ukrainian Food Journal, 8(2), pp. 294-306.

20. O.O. Biloukha, V. Utermohlen (2000), Correlates of food consumption and perceptions of foods in an educated urban population in Ukraine, Food Quality and Preference, 11(6), pp. 475-485.

21. Ivan Machado Martins, Rodrigo Pereira Medeiros, Maikon Di Domenico, Natalia Hanazaki (2018), What fishers' local ecological knowledge can reveal about the changes in exploited fish catches, Fisheries Research, 198, pp. 109-116.

22. Jakia Sultana Jothi, Ishrat Zahan Anka, Shaharior Hashem, Shamsul Morshed (2018), Assessment of heavy metal concentration in edible fish muscle and water sample collected from different location in Chittagong: a public health concern, Ukrainian Food Journal, 7(3), pp. 464-471.

23. Samsonov V., Hlobystova O., Mazurenko O., Taran A. (2013), The operational reliability of complex energy facilities, Ukrainian Food Journal, 2(4), pp. 575-580.

24. Tao Huang, Zong-cai Tu, Xinchen Shangguan, Xiaomei Sha, Nidhi Bansal (2019), Fish gelatin modifications: A comprehensive review, Trends in Food Science \& Technology, 86, pp. 260-269.

25. J. Tolosa, G. Font, J. Mañes, E. Ferrer (2017), Mitigation of enniatins in edible fish tissues by thermal processes and identification of degradation products, Food and Chemical Toxicology, 101, pp. 67-74.

26. Fangkai Han, Xingyi Huang, Gustav Komla Mahunu (2017), Exploratory review on safety of edible raw fish per the hazard factors and their detection methods, Trends in Food Science \& Technology, 59, pp. 37-48.

27. Silvia Grassi, Ernestina Casiraghi, Cristina Alamprese(2018), Fish fillet authentication by image analysis, Journal of Food Engineering, 234, pp. 16-23.

28. Laura Otero, Miriam Pérez-Mateos, Antonio C. Rodríguez, Pedro D. Sanz (2017), Electromagnetic freezing: Effects of weak oscillating magnetic fields on crab sticks, 


\section{Food Technology}

Journal of Food Engineering, 200, pp. 87-94.

29. Laura Campo-Deaño, Clara Tovar (2009), The effect of egg albumen on the viscoelasticity of crab sticks made from Alaska Pollock and Pacific Whiting surimi, Food Hydrocolloids, 23(7), pp. 1641-1646.

30. Hur S.J., Choi B.D., Choi Y.J., Kim B.G., Jin B.G. (2011), Quality characteristics of imitation crab sticks made from Alaska Pollack and spent laying hen meat, LWT-Food Science and Technology, 44(6), pp. 1482-1489.

31. Xiaochang Liu, Na Qin, Yongkang Luo (2016), Application of a combination model based on an error-correcting technique to predict quality changes of vacuum-packed bighead carp (Aristichthys nobilis) fillets, $L W T$, 74, pp. 514-520.

32. Wenhong Gao, Rui Hou, Xin-an Zeng (2019), Synergistic effects of ultrasound and soluble soybean polysaccharide on frozen surimi from grass carp, Journal of Food Engineering, 240, pp. 1-8.

33. Yanshun Xu, Wenshui Xia, Fang Yang, Xiaohua Nie (2010), Protein molecular interactions involved in the gel network formation of fermented silver carp mince inoculated with Pediococcus pentosaceus, Food Chemistry, 120(3), pp. 717-723.

34. Yueqi An, Juan You, Shanbai Xiong, Tao Yin (2018), Short-term frozen storage enhances cross-linking that was induced by transglutaminase in surimi gels from silver carp (Hypophthalmichthys molitrix), Food Chemistry, 257, pp. 216-222.

35. Longteng Zhang, Qian Li, Jing Shi, Beiwei Zhu, Yongkang Luo (2018), Changes in chemical interactions and gel properties of heat-induced surimi gels from silver carp (Hypophthalmichthys molitrix) fillets during setting and heating: Effects of different washing solutions, Food Hydrocolloids, 75, pp. 116-124.

36. Mehdi Abdollahi, Masoud Rezaei, Ali Jafarpour, Ingrid Undeland (2017), Dynamic rheological, microstructural and physicochemical properties of blend fish protein recovered from kilka (Clupeonella cultriventris) and silver carp (Hypophthalmichthys molitrix) by the $\mathrm{pH}$-shift process or washing-based technology, Food Chemistry, 229, pp. 695-709.

37. Qian Liu, Qian Chen, Baohua Kong, Jianchun Han, Xueying He (2014), The influence of superchilling and cryoprotectants on protein oxidation and structural changes in the myofibrillar proteins of common carp (Cyprinus carpio) surimi, LWT - Food Science and Technology, 57(2), pp. 603-611.

38. Horalchuk A.B., Pyvovarov P.P., Hrynchenko O.O. (2006), Reolohichni metody doslidzhennia syrovyny i kharchovykh produktiv ta avtomatyzatsiya rozrakhunkiv reolohichnykh kharakterystyk, Kharkiv.

39. Moore D.A., Taylor J., Hartman M.L., Sischo W.M. (2009), Quality assessments of waste milk at a calf ranch, Journal of Dairy Science, 92 (7), pp. 3503-3509.

40. Ione L.S. Almeida, Mônica D.R. Oliveira, José B.B. Silva, Nívia M.M. Coelho (2016), Suitable extraction of soils and sediments for mercury species and determination combined with the cold vapor generation atomic absorption spectrometry technique, Microchemical Journal, 124, pp. 326-330.

41. Kuzmin O., Pozdniakov S., Kiiko V., Akimova L. (2018), Development of quality management systems in the hotel-restaurant business, Transformational processes the development of economic systems in conditions of globalization: scientific bases, mechanisms, prospects, Riga: ISMA University, Vol. 1, pp. 221-232.

42. Kuzmin O., Pasichnyi V., Levkun K., Riznyk A. (2017), Determination of the factor space of the process of extrusion of sausage products, Ukrainian Journal of Food Science, 5(1), pp. 54-62.

43. K.S Khairou, W.M Al-Gethami, R.M HasMontero (2002), Kinetics and mechanism of 
sol-gel transformation between sodium alginate polyelectrolyte and some heavy divalent metal ions with formation of capillary structure polymembranes ionotropic gels, Journal of Membrane Science, 209(2), pp. 445-456.

44. M. Pérez-Mateos, T. Solas, P. Montero (2002), Carrageenans and alginate effects on properties of combined pressure and temperature in fish mince gels, Food Hydrocolloids, 16(3), pp. 225-233.

45. Helena M. Moreno, José Carballo, A. Javier Borderías (2010), Use of microbial transglutaminase and sodium alginate in the preparation of restructured fish models using cold gelation: Effect of frozen storage, Innovative Food Science \& Emerging Technologies, 11(2), pp. 394-400.

46. P. Montero, M. Pérez-Mateos (2002), Effects of $\mathrm{Na}^{+}, \mathrm{K}^{+}$and $\mathrm{Ca}^{2+}$ on gels formed from fish mince containing a carrageenan or alginate, Food Hydrocolloids, 16(4), pp. 375385.

47. Lee Kuen Yong, David J. Mooney (2012), Alginate: properties and biomedical applications, Progress in polymer science, 37(1), pp. 106-126.

48. Senturk Parreidt T., Müller K., Schmid M. (2018), Alginate-based edible films and coatings for food packaging applications, Foods, 7(10), pp. 170.

49. Tønnesen H.H., Karlsen J. (2002), Alginate in drug delivery systems, Drug development and industrial pharmacy, 28(6), pp. 621-630. 